\title{
The Effects of Indoor Environment towards Middle-Income Group in Re-engineered Affordable Housing Scheme in Malaysia
}

\author{
Syahrul Nizam Kamaruzzaman*1, Atikah Razali", Emma Marinie Ahmad Zawawi², \\ Michael Riley ${ }^{3}$ \\ ${ }^{1}$ Centre for Building, Construction \& Tropical Architecture (BuCTA), Faculty of Built \\ Environment, University of Malaya, 50603 Kuala Lumpur, Malaysia. \\ ${ }^{2}$ Faculty of Architecture, Planning \& Surveying, University Technology Mara, Shah Alam, \\ Selangor, Malaysia. \\ ${ }^{3}$ Department of Built Environment, Faculty of Engineering and Technology, Liverpool John \\ Moores University, Liverpool, United Kingdom.
}

*syahrulnizam@um.edu.my

Received : 14 August 2017 Final Version Received: 15 January 2018

The innovation of housing has evolved due to several issues such as the affordability and the sustainability of housing. Several housing designs were introduced to meet the affordable housing standard price for the middle-income group, particularly in the urban area. However, it is a challenge for the developers to provide affordable housing within the current market price with the element of sustainability. The developers use the concept of high rise building form and located near the public amenities to accommodate the users' needs as well as to gain profits. Despite the rising demands, there is a limited study that focuses on the performance of the buildings, specifically on the indoor environmental quality (IEQ) of the affordable housing. This paper aims to assess the affordable housing performance by identifying the residents' satisfaction level towards IEQ and the importance of the IEQ factors as well as their health condition. A questionnaire survey is one of the methods used in this study. The findings showed that the IEQ of affordable housing in Malaysia has resulted in the decrease of health towards the residents, with some dissatisfaction towards the IEQ. The insight from the residents can be used as an indicator to improve the IEQ as well as the building performance and to create a better affordable housing in Malaysia.

Keywords: Indoor environmental quality, affordable housing, environmental health, building performance, building occupants.

\section{INTRODUCTION}

Malaysia is facing the design innovation and policy evolution of housing due to the global financial crisis, land mitigation and global environmental issue (Lim, 2016; Malaysia Productivity Corporation, 2010). Therefore, the Malaysia government uses affordable housing as an approach to overcome this issue. This approach has also been used in several developed countries such as Hong Kong. Kee (2014) pointed out that affordable housing scheme in Hong Kong has adopted the housing blocks design in order to accommodate the increasing demand for affordable housing. Moreover, he added that the Hong Kong government has considered the approach of reusing old buildings and adapting it into an affordable housing unit.

According to Crump (2011) and Baqutaya et al (2016), the design and policy of housing have changed as both are focusing on sustainability and affordable housing to obtain a healthy lifestyle, inclusive, and conducive environment. In order to achieve this, as Gambero (2014), Lim (2016), and $\mathrm{Ng}$ (2016) suggested, a new type of housing design had been adopted by the developers. They started to construct on strata properties instead of on landed properties. Moreover, Lim (2016) said that there are various characteristics implemented by the developer to the new innovation of housing including variety of the built-up areas, furnishes, distance to public amenities, and facilities. Tremendous numbers of housing units were occupied and constructed due to the rising demand for affordable housing.

According to the Eleventh Malaysia Plan (2016-2020), the government of Malaysia has instigated several measures in order to provide affordable housing for the citizens, such as MyHome and PR1MA. REHDA (2015) has 
taken the initiative to sum up the proposed actions regarding the housing and property as shown in Table 1.

Table 1: Home Ownership / Affordable Housing by REHDA (2015)

\begin{tabular}{lll}
\hline Programme 1 & $:$ & PR1MA to build 175, 000 houses which will be sold at 20\% below market price \\
& $:$ & A total of 10,000 units are expected to be completed next year \\
\hline Programme 2 & $: \begin{array}{l}\text { Build 100,000 houses, priced between RM90, 000 to RM300, 000 under } \\
\text { Perumahan Penjawat Awam 1Malaysia (PPA1M) by 2018. }\end{array}$ \\
& A facilitation fund of up to 25\% of development cost is provided. \\
Programme 3 & $\begin{array}{l}\text { Build 22,300 units of apartments and 9, } 800 \text { units of terraced houses under the } \\
\text { People's Housing Programme (PPR) with an allocation of RM863 million to } \\
\text { KPKT. }\end{array}$
\end{tabular}

Establish a First Home Deposit Financing Scheme under KPKT to assist first-

Programme 4 : time house buyers of affordable housing to pay the deposit with an allocation of RM200 million.

$\begin{array}{ll}\text { Programme 5 } & \begin{array}{l}\text { Build 5,000 units of PR1MA and PPA1M houses in } 10 \text { locations in the vicinity } \\ \text { of LRT and monorail stations, including in Pandan Jaya, Sentul, and Titiwangsa. }\end{array}\end{array}$

Programme 6 : GLCs to build affordable houses in the vicinity of the MRT station in Bandar Kwasa Damansara.

KWASA Land Owned by EPF and Sime Darby will build 800 units and 4,600 units respectively.

\begin{abstract}
As a reflection from the affordability housing issues, massive numbers of affordable houses with new innovation have been constructed and occupied since 2010. Thus, the concern and uncertainty on the quality of the indoor environment quality (IEQ) due to commonly attributed adverse effects on comfort, health and productivity must be looked at (Haghighat and Donnini 1999). In parallel with the government agenda to provide a conducive living environment for the citizens, residents' feedback towards affordable housing is one of the primary sources as a step for the betterment of the living environment.
\end{abstract}

Even though affordable housing is designed to meet the physical recommended standard i.e. meet the requirement of the Malaysian
Standards (MS), it is still uncertain on the IEQ in the buildings. Monitoring the IEQ of a building or unit is essential, because according to a study by Klepeis et al. (2001) in America, averagely an individual spent $86.9 \%$ of their time indoors, and $68.7 \%$ of them in their own residents. Thus, it is axiomatic that people are exposed to the indoor environment more than outdoor environment (Schweizer et al., 2007; LPPKN, 2013; Kamaruzzaman et al., 2011). Researchers such as Lee et al. (2011), Crump (2011), and IOM (2011) had proven that poor IEQ exposed the residents to health problems. Cooper et al. (2009) had provided a list of the impacts of the inadequate physical environment towards the well-being of building occupants as shown in Table 2.

Table 2: Trends in physical environment and their impact on the well-being

\begin{tabular}{|c|c|c|c|c|}
\hline \multirow{2}{*}{ Trend } & \multicolumn{3}{|c|}{ Impact } & \multirow{2}{*}{ Comment/Example } \\
\hline & Positive & Negative & Both & \\
\hline Short-termism & & $\mathrm{x}$ & & $\begin{array}{l}\text { Quick wins of short-term gains might not benefit } \\
\text { people's mental well-being in the long-term }\end{array}$ \\
\hline Zero carbon & $\mathrm{x}$ & & & Direct impact on health (mental and physical) \\
\hline $\begin{array}{l}\text { Increased } \\
\text { density }\end{array}$ & & & $\mathrm{x}$ & $\begin{array}{l}\text { Might stimulate social integration, but also } \\
\text { segregation (ghettos). More people in a space might } \\
\text { negatively impact on stress levels }\end{array}$ \\
\hline
\end{tabular}




\begin{tabular}{|c|c|c|c|}
\hline Polarisation & $\mathrm{x}$ & & $\begin{array}{l}\text { Possible stimulation of different dimensions } \\
\text { segregation and therefore may impact negatively on } \\
\text { mental health }\end{array}$ \\
\hline $\begin{array}{l}\text { Commercialism } \\
\text { and mono- } \\
\text { functionalism }\end{array}$ & $\mathrm{x}$ & & $\begin{array}{l}\text { Reduced ability to freely enjoy and use spaces in } \\
\text { multitude of ways }\end{array}$ \\
\hline $\begin{array}{l}\text { Ubiquitous } \\
\text { environment }\end{array}$ & & $\mathrm{x}$ & $\begin{array}{l}\text { Potential increases in sedentary lifestyles leading to } \\
\text { feelings of isolation. Better monitoring of health } \\
\text { conditions creating increased feelings of control }\end{array}$ \\
\hline $\begin{array}{l}\text { Engineering } \\
\text { quality out }\end{array}$ & $\mathrm{x}$ & & $\begin{array}{l}\text { Poorly designed environments can reinforce } \\
\text { depression and human degradation }\end{array}$ \\
\hline $\begin{array}{l}\text { Virtual social } \\
\text { communities }\end{array}$ & & $\mathrm{x}$ & $\begin{array}{l}\text { Potential physical and psychological isolation, } \\
\text { although possibilities of virtual engagement which } \\
\text { could increase tolerance/reduce isolation }\end{array}$ \\
\hline $\begin{array}{l}\text { Mitigation of } \\
\text { risk }\end{array}$ & & $\mathrm{x}$ & $\begin{array}{l}\text { Making environments safer, although bland and } \\
\text { monotonous }\end{array}$ \\
\hline Surveillance & & $\mathrm{x}$ & $\begin{array}{l}\text { Making environments safer, although possibly } \\
\text { enhancing paranoia }\end{array}$ \\
\hline
\end{tabular}

Physical environment, according to Davison and Lawson (2006), as cited in Cooper et al. (2009), is the "objective and perceived characteristics of the physical context in which people spend their time including aspects of urban design, traffic density, distance to and design of venues, crime, safety and weather conditions". Cooper et al. (2009) had proven the link between physical environment and the health condition of building occupants, which is called "sick building syndrome (SBS)" (Lee et al, 2001). Lee (2001) further relates the SBS impacts towards the residential health, for instance, the cleanliness of public facilities and the indoor ventilation performance will affect the physical health of the residents. However, he did not list the symptoms of SBS. Therefore, the issue of SBS should be addressed seriously since the trends of housing changes from a bungalow to "building" form or also known as multiple housing. Furthermore, the symptoms of SBS should be identified accordingly in order to specifically relate the health condition of the occupants of an affordable housing in Malaysia.

According to Baqutaya et al (2016), high-rise buildings such as flats and apartments, contribute to the unhealthy lifestyle and social issues in Malaysia. In addition, Lee (2011) stated that the SBS has further enhanced the concern of the occupants towards their physical and mental health and lifestyle. Ergo, it is a paramount step in evaluating the residents' health and feedback towards the IEQ of the affordable housing and as according to Hashim (2010), there is no specific study made on affordable housing that dealt with the issues of the affordable housing. Thus, more research need to be conducted especially in the perspective to optimise the Malaysian building standards for the benefit of the occupants.

It is essential for these buildings to have an adequate IEQ, as it affects the productivity and health of the building occupants. It is critical to see that sustainable development results not just in the resource conservation, but also in increasing the productivity and the occupants' well-being. This study hopes to inform the design community on the occupants' perception of performance based on IEQ criteria. This study will add to the growing body of research on sustainable design and occupant's perception towards IEQ.

\section{METHODOLOGY}

There were a few stages in preparing this study. The first stage was the literature review, where materials such as journals, case studies, articles, and books related to the topic of this study were explored, discussed, and comprehended. Then, a questionnaire survey was made and tested in a piloted study. The purpose of this pilot survey was to determine the efficiency and accuracy of the questionnaire. Furthermore, any changes and comments regarding the questionnaire were taken into consideration for amendment to the main questionnaire survey. The main survey was conducted at four selected apartments within the Klang Valley. Next, the data collected from the questionnaire survey were discussed and critically analyzed by using the SPSS software.

\subsection{Study Design}

Four apartments in the Klang Valley were selected as the case study to assist in this research as per Table 3. These four case studies 
were labelled as Apartment A, Apartment B, Apartment C, and Apartment D. All four apartments are located in the Klang Valley and comprised of high-rise residential housing and are near to public transportation such as bus station, commercial hubs, LRT station, and commuter station. All of the apartments consist of three to four bedrooms, two to three bathrooms, a dining and a living space. However, they are varied in terms of built-up area in the range of $815 \mathrm{sqft}$ to $1,651 \mathrm{sqft}$.

Table 3: Particular Detail of Case Studies

\begin{tabular}{|c|c|c|c|c|}
\hline & Apartment A & Apartment B & Apartment $\mathrm{C}$ & Apartment D \\
\hline Location & $\begin{array}{l}\text { Bandar Sri Permaisuri, } \\
\text { Cheras, Kuala Lumpur. }\end{array}$ & $\begin{array}{l}\text { Jalan Budiman, } \\
\text { Shah Alam. }\end{array}$ & $\begin{array}{l}\text { Presint } 11, \\
\text { Putrajaya. }\end{array}$ & $\begin{array}{l}\text { Taman Tasik } \\
\text { Permaisuri, Cheras, } \\
\text { Kuala Lumpur. }\end{array}$ \\
\hline Build-up area & 830 sqft & 850 to $1,651 \mathrm{sqft}$ & 815 to 1,006 sqft & 820 sqft \\
\hline $\begin{array}{l}\text { Numbers of } \\
\text { Blocks }\end{array}$ & 2 blocks - 15 storey & $\begin{array}{l}1 \text { block - } 16 \\
\text { storey }\end{array}$ & $\begin{array}{l}3 \text { Blocks } \\
\text { - Block A - } 11 \\
\text { storey } \\
\text { - Block B \& C - } \\
14 \text { storey }\end{array}$ & $\begin{array}{l}2 \text { Blocks } \\
\text { - Block A - } 12 \\
\text { storey } \\
\text { - Block B - } 13 \\
\text { storey }\end{array}$ \\
\hline $\begin{array}{l}\text { Numbers of } \\
\text { Units }\end{array}$ & 600 units & 435 unit & 560 units & 540 units \\
\hline Space & $\begin{array}{l}3 \text { bedrooms, } \\
2 \text { bathrooms, } \\
\text { Dining and Living space }\end{array}$ & $\begin{array}{l}\text { Type A: } 850 \text { sqft; } \\
3 \text { bedrooms, } \\
2 \text { bathrooms. } \\
\text { Type B: } 771 \text { sqft; } \\
3 \text { bedrooms, } \\
2 \text { bathrooms. } \\
\text { Type C: } 1,725 \\
\text { sqft; } \\
4 \text { bedrooms, } \\
3 \text { bathrooms. } \\
\text { Type } \mathbf{D} ; 1,621 \\
\text { sqft; } \\
4 \text { bedrooms, } \\
3 \text { bathrooms. }\end{array}$ & $\begin{array}{l}3 \text { bedrooms, } \\
2 \text { bathrooms, } \\
\text { Dining and Living } \\
\text { space }\end{array}$ & $\begin{array}{l}3 \text { bedrooms, } \\
2 \text { bathrooms, } \\
\text { Dining and Living } \\
\text { space }\end{array}$ \\
\hline
\end{tabular}

\subsection{Questionnaire Survey}

Convenience sampling was used to conduct the questionnaire survey in four different areas of affordable housing scheme within the Klang Valley as per detailed in Table 3. Questionnaire surveys were used to document the residents' perspective towards their housing unit. The questionnaire requested the respondents of their basic information such as age and gender. Then, it questioned the health condition of the respondents as well as their satisfaction level towards the IEQ of their unit. In short, the questionnaires were divided into three sections as follows: i. Section A - Demographic,

ii. Section B - Health assessment of the residents; and

iii. Section C - To assess the level of satisfaction and the important factors of IEQ from the residents.

The questionnaire used the 5-point Likert scale to question the satisfaction level and the level of importance of the IEQ factors. Additionally, the Likert scale was also used to rate the frequency of the SBS symptoms. The summary of the 5point Likert is as Table 4.

Table 4: The labels of 5-Point Likert scale used in the study

\begin{tabular}{lll}
\hline Frequency of Symptoms & Satisfaction Level & Importance Factor \\
\hline $1=$ Never & $1=$ Extremely Dissatisfied & $1=$ Most Unimportant \\
$2=$ Rarely & $2=$ Dissatisfied & $2=$ Unimportant \\
$3=$ Sometimes & $3=$ Neutral & $3=$ Neutral
\end{tabular}




\begin{tabular}{lll}
$4=$ often & $4=$ Satisfied & $4=$ Important \\
$5=$ Very Often & $5=$ Extremely satisfied & $5=$ Most important \\
\hline
\end{tabular}

The method used to distribute the questionnaire is by hand on four of the apartments. The questionnaires were distributed with the sample size of $(n=384)$ in February 2017. According to Table 5 , the response rate of the data collection is $34.375 \%$ where only 132 sets were returned.
The questionnaires were distributed equally at the four locations. However, not all of the questionnaires were returned and the number of returned questionnaires varies from each apartment. This significantly impacted the final result of this study.

Table 5: Research sample and percentage of response rate

\begin{tabular}{lccc}
\hline Location & $\begin{array}{l}\text { No of Distributed } \\
\text { Questionnaire }\end{array}$ & $\begin{array}{l}\text { No of Returned } \\
\text { Questionnaire }\end{array}$ & $\begin{array}{c}\text { Percentage (\%) of } \\
\text { response rate }\end{array}$ \\
\hline Apartment A & 96 & 45 & 46.875 \\
Apartment B & 96 & 24 & 25 \\
Apartment C & 96 & 20 & 20.83 \\
Apartment D & 96 & 43 & 44.79 \\
\hline Total & 384 & 132 & $34.375 \%$ \\
\hline
\end{tabular}

\section{RESULTS AND DISCUSSION}

\subsection{Literature review}

\subsubsection{Affordable housing}

In the recent years, the government of Malaysia has been attending to the demand of their citizens on affordable housing, especially for the middle-income group in the urban area (Baqutaya et al, 2016). According to United Nations Human Settlements Programme (2011) as cited by Ling and Almeida (2016), affordable housing can be defined as a housing that is proper in quality and location. More importantly, the cost of the house does not prevent the buyers from meeting their daily basic needs. Furthermore, they stated that affordable housing is "when the median price of the market is three times the gross annual household income." They also suggested that the range of affordable housing is between RM165,000 and RM242,000. However, in this study, affordable housing considers the lowcost and medium-low-cost houses that range from RM250,000 to RM400,000 with the builtup area less than 1,700sqft. Crump (2011) and Baqutaya et al (2016) suggested that the design and policy of buildings have changed the focus towards sustainability and affordable housing. Thus, the Malaysian government has proposed in their Eleventh Malaysia Plan to instigate numerous steps to accommodate the demand such as PR1MA and MyHome. This development has been supported by several developers in Malaysia to accommodate the demand. However, it is a challenging process to achieve the pricing standard and sustainability together. Therefore, according to
Lim (2016) and $\mathrm{Ng}$ (2016), the developers have adopted a new type of housing such as high-rise building into their design concept. This concept met the demand of the users as well as enabled the developer to gain profit. On the other side, this solution might overlook the environmental quality of the unit on post occupancy, because as according to Haghighat and Donnini (1999), there is a concern on the IEQ due to the commonly attributed adverse effect of comfort, health, and productivity.

\subsubsection{Indoor Environmental Quality (IEQ)}

According to the National Institute for Occupational Safety and Health (NIOSH) (2013), indoor environmental quality (IEQ) is the environmental quality of a building that is related to health and the well-being of the occupants. The Institute of Medicine (IOM) (2011) stated that a poor IEQ affects the comfort and health condition of the residents. Crump (2011) and Kamaruzzaman et al (2011) also agrees that the IEQ has become important as it impacted the dwellers of the unit, especially on their comfort and health. Therefore, the IEQ of a dwelling should be taken into account when designing a house or a building. Malina et al (2017) pointed out that the effects of IEQ of a space were not given a proper consideration by the occupants due to the limited knowledge regarding the aspects of IEQ. It had been found that there are approximately 20 variables of the IEQ condition, such as ventilation (Nimlyat \& Kandar, 2015), temperature (Norhidayah et al, 2013; Nimlyat \& Kandar, 2015), noise pollution (Nimlyat \& Kandar, 2015; 
Martellotta et al, 2016), and daylight (Nimlyat \& Kandar, 2015), to name a few. Table 6 lists the twenty variables found in the literature review.

Table 6: Aspects affected IEQ

\begin{tabular}{ll|ll}
\hline \multicolumn{1}{c|}{ Aspects } & \multicolumn{1}{c}{ Aspects } \\
\hline 1. & Noise level & 11. & Relative humidity \\
2. & Amount of artificial lighting & $12 . \quad$ Odour \\
3. & Amount of daylight & $13 . \quad$ Health \\
4. & Glare level in the unit & $14 . \quad$ Colours of unit \\
5. & Glare level around room & $15 . \quad$ Attractiveness of unit \\
6. & Window distance & $16 . \quad$ Control over the environment \\
7. & Temperature & $17 . \quad$ Privacy \\
8. & Ventilation & $18 . \quad$ Unit in General \\
9. & Air movement & $19 . \quad$ Façade appearance \\
10. & Unit freshness & $20 . \quad$ Amount of space \\
\hline
\end{tabular}

The variables were categorized into several groups based on the questionnaire results. Kaiser-Meyer-Olkin (KMO) Measure and Bartlett's Test were used to categorize the items (see Section 3.3 below).

\subsubsection{Sick Building Syndrome}

According to the United States Environmental Protection Agency (EPA), SBS is a term used to describe a condition where the "occupants experience acute health and comfort effect" that is related to the time spent in a building. However, they further explained that there are no specific illnesses or causes can be identified. The EPA pointed that in 1984, the World Health Organization (WHO) reported that 30\% of the re-engineered or remodelled buildings may be subjected to complaints regarding the indoor air quality (IAQ) of the building. They documented that the symptoms complained by the occupants were headache, irritation of eyes, nose or throat, dry coughing, itchiness, dizziness, nausea, difficulties in breathing, difficulties in concentrating, fatigue and more. Martin - Gil et al (1997) added allergies, and increased incidence of asthma attack. However, as mentioned before, the cause of these symptoms is still uncertain, but the respondents felt relieved when leaving the building. The list of SBS symptoms are as follows:

$\begin{array}{ll}\text { i. } & \text { Headache } \\ \text { ii. } & \text { Eyes, nose, and throat irritation, } \\ \text { iii. } & \text { Dry cough } \\ \text { iv. } & \text { Dry or itchy skin }\end{array}$

$\begin{array}{ll}\text { v. } & \text { Dizziness and nausea } \\ \text { vi. } & \text { Difficulty in concentrating } \\ \text { vii. } & \text { Fatigue } \\ \text { viii. } & \text { Sensitive to odour } \\ \text { ix. } & \text { Chest tightness } \\ \text { x. } & \text { Fever } \\ \text { xi. } & \text { Allergies } \\ \text { xii. } & \text { Shortness of breath } \\ \text { xiii. } & \text { Sinus } \\ \text { xiv. } & \text { Flu-like symptoms (i.e. sneezing) } \\ \text { xv. } & \text { Stress } \\ \text { xvi. } & \text { Anxiety } \\ \text { xvii. } & \text { Annoyance } \\ \text { xviii. } & \text { Stuffy nose }\end{array}$

\subsection{Survey Findings}

\subsubsection{Respondents Characteristics}

From the questionnaire, it was found that the majority of the respondents were female with $62 \%$ compared to male (38\%). More so, most of the respondents were in the age between 26 to 35 years old with $41 \%$, followed by 36 to 45 years old with $30 \%$, and 18 to 25 years old (14\%). Furthermore, most of them were the owner of the apartment unit $(62 \%)$ while the rest $38 \%$ of them were the tenants. Most of the household size consists less than four people per unit $(43 \%)$ followed by more than 4 people per unit $(34 \%)$. Finally, the majority of the respondents had occupied the unit in less than five years $(63 \%)$ followed by 6 to 10 years (19\%). Table 7 shows the summary of the characteristics of the respondents. 
Table 7: Characteristic of respondents

\begin{tabular}{|c|c|c|c|}
\hline & & Frequency & Percentage $(\%)$ \\
\hline \multirow[t]{3}{*}{ Gender } & Male & 50 & 38 \\
\hline & Female & 82 & 62 \\
\hline & Total & 132 & 100 \\
\hline \multirow[t]{6}{*}{ Age (years) } & $18-25$ & 19 & 14 \\
\hline & $26-35$ & 55 & 41 \\
\hline & $36-45$ & 39 & 30 \\
\hline & $46-55$ & 13 & 10 \\
\hline & 55 years and above & 6 & 5 \\
\hline & Total & 132 & $100 \%$ \\
\hline \multirow[t]{3}{*}{ Ownership status } & Owner & 82 & 62 \\
\hline & Tenant & 50 & 38 \\
\hline & Total & 132 & $100 \%$ \\
\hline \multirow[t]{4}{*}{ Household size (person) } & Less than 4 & 57 & 43 \\
\hline & 4 & 30 & 23 \\
\hline & More than 4 & 45 & 34 \\
\hline & Total & 132 & $100 \%$ \\
\hline \multirow[t]{5}{*}{ Period of residency (years) } & Less than 1 year & 7 & 5 \\
\hline & $1-5$ & 83 & 63 \\
\hline & $6-10$ & 25 & 19 \\
\hline & More than 10 years & 17 & 13 \\
\hline & Total & 132 & $100 \%$ \\
\hline
\end{tabular}

\subsubsection{Respondents Health Condition}

Table 8 shows the residents' health condition ever since they lived in their affordable housing unit. It was discovered that about $17 \%$ of the residents living in affordable housing unit have experienced the decreased of their health condition. Even though the margins between the increase in health and the decrease in health were minimal, $48 \%$ of the respondents have seen the doctor for consultation of their health problems related to the SBS symptoms. Furthermore, $45 \%$ of the respondents spent six to ten hours in their dwelling and followed by 11 to 15 hours $(27 \%)$. Therefore, the residents these four apartments are more likely to be exposed to the indoor environment of their units than outdoor environment, which resulted in either the decrease of health or affected by the SBS symptoms, or both.

Table 8: Residents' health condition and the hours spent in the unit

\begin{tabular}{|c|c|c|c|}
\hline & & Frequency & Percentage (\%) \\
\hline \multirow{3}{*}{ Seen Doctor } & Yes & 63 & 48 \\
\hline & No & 69 & 52 \\
\hline & Total & 132 & $100 \%$ \\
\hline \multirow{4}{*}{ Health Condition } & Increasing & 24 & 18 \\
\hline & Decreasing & 22 & 17 \\
\hline & No Changes & 86 & 65 \\
\hline & Total & 132 & $100 \%$ \\
\hline \multirow{6}{*}{$\begin{array}{l}\text { Times spent in the } \\
\text { unit (hours) }\end{array}$} & $0-5$ & 5 & 4 \\
\hline & $6-10$ & 59 & 45 \\
\hline & $11-15$ & 36 & 27 \\
\hline & $16-20$ & 13 & 10 \\
\hline & $21-24$ & 19 & 14 \\
\hline & Total & 132 & $100 \%$ \\
\hline
\end{tabular}

Figure 1 shows the health symptoms experienced by the residents by calculating the total score. It was found that the most severe symptoms among the residents are fatigue, headache, sneezing, stress, coughing, and sinus. According to Nimlyat and Kandar (2015), 
Frontczak and Wargocki (2011), Abdul-Wahab et al. (2015), and Yousef et al. (2016), the symptoms that occurred among the residents are due to inadequate IEQ. Moreover, House and Keeling (2009) suggested that the household members influence the illness transmission within the household. More so, Cauchemez, Carrat, Viboud, and Boëlle (2004) conducted a study on the transmission of influenza on 344 households and found that the illness transmission duration decreases within a smaller size household. Therefore, the number of household in the unit influences the health condition of the residents as diseases or illness might spread within the household, where based on the survey, it has been found that $34 \%$ of the respondents live in a unit that consists of more than four people.

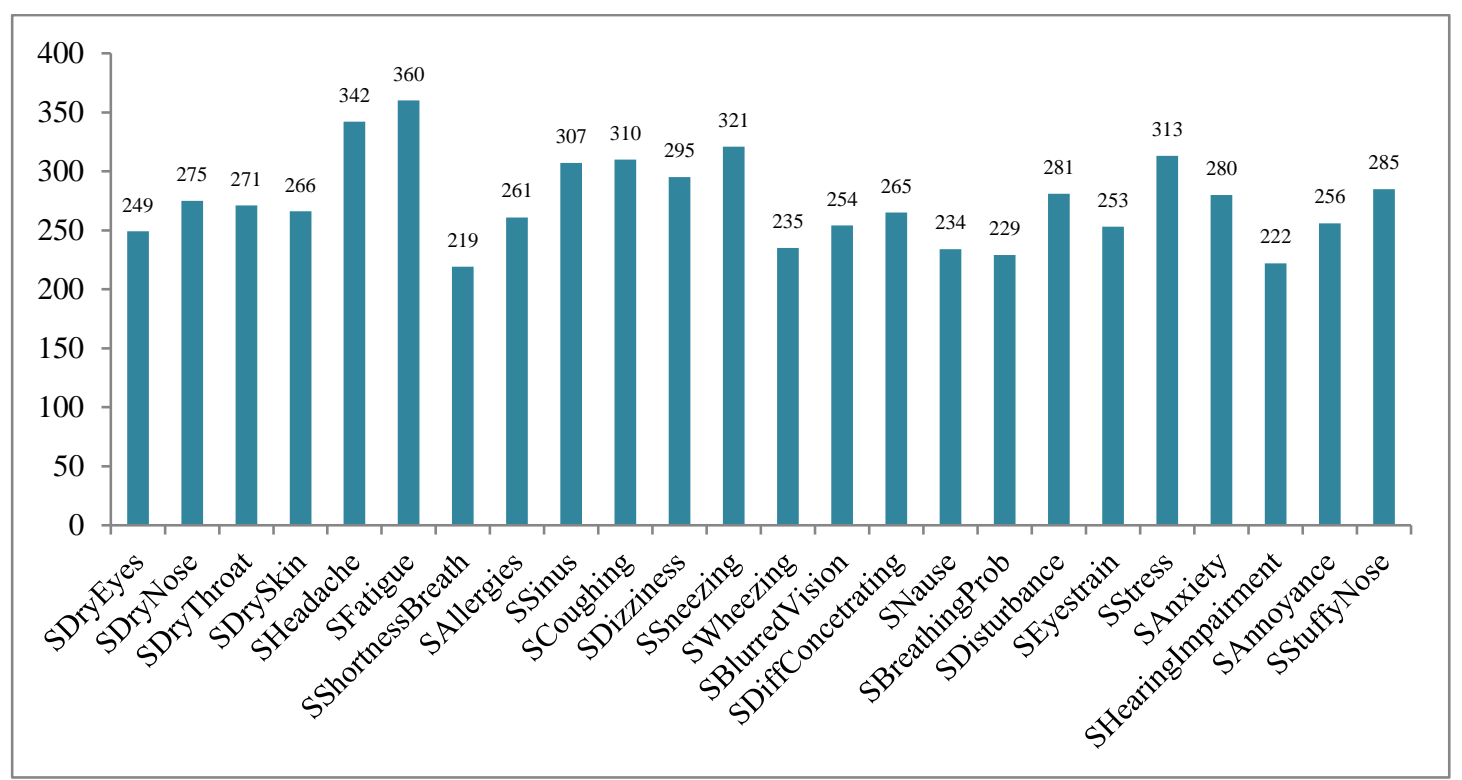

Figure 1: Total score on the symptoms experienced by respondents

Thus, it can be concluded that the IEQ in an affordable housing needs some improvement to achieve a proper IEQ. It is not possible to compare the symptoms along with the apartments due to the abnormal distribution of respondents at the site of the study. However, based on the site survey, Apartment A and Apartment D were located near public amenities, such as commercial hubs, bus stations, and highways, within $1 \mathrm{~km}$ away from the East-West Link Express Highway. Apartment B was located opposite an ongoing construction site on top of being within 200 meters away from ELITE Highway while Apartment C was located within 500 meters behind the Putrajaya - Cyberjaya Expressway and within $1 \mathrm{~km}$ radius from Maju Expressway (MEX). All the four locations are located near a highway, or highways, where the concentration of carbon monoxide and smoke produced by the vehicles are high. Thus, the location of the apartments as well as its surrounding contributed to the air pollution and eventually infected the indoor air environment of the apartments. The summary of the public amenities and highways are as in Table 9.

Table 9: Radius distance to public amenities from apartments

\begin{tabular}{l|llll}
\hline \multicolumn{2}{l}{ Apartment A } & Apartment B & Apartment C & Apartment D \\
\hline $\begin{array}{l}\text { Bus station/bus } \\
\text { stop }\end{array}$ & Within 500m radius & Within 1km radius & Within 200m radius & Within 500m radius \\
\hline Commercial Hub & Within 1km radius & Within 500m radius & Within 500m radius & Within 500m radius \\
\hline \multirow{3}{*}{ Highway } & Within 1 km radius: & Within 200m & Within 500m & Within 1km radius: \\
& E37 - East -West & radius: & radius: & E37 - East - West \\
& Link Express & AH2 - ELITE & 29- Putrajaya - & Link Express \\
& Highway & Highway & Cyberjaya & Highway \\
& & & Expressway & \\
& & & Within 1km radius: & \\
& & & E20-Maju & \\
\hline
\end{tabular}




\begin{tabular}{l|llll}
\hline & \multicolumn{3}{c}{ Expressway (MEX) } \\
\hline \multirow{3}{*}{ Public Park } & Within 500m & Within 500m & Within 1km: & Within 1km radius: \\
& radius: Taman & radius: Nirvana & Taman Saujana & Taman Tasik \\
& Tasik Permaisuri & Memorial Park & Hijau & Permaisuri \\
\hline
\end{tabular}

\subsubsection{Satisfaction Level of Respondents}

Table 10 indicates the median of the 5-point Likert scale on the satisfaction level of the residents towards the IEQ of their housing units. Value 3 shows the average levels of satisfaction of the respondents, while values 2 and 1 shows their dissatisfaction and values 4 and 5 indicate the satisfaction level.

Table 10: Satisfaction level if respondents on IEQ

\begin{tabular}{|c|c|c|c|c|}
\hline \multirow{3}{*}{ Factors } & \multicolumn{4}{|c|}{ Satisfaction level } \\
\hline & A & B & $\mathrm{C}$ & D \\
\hline & \multicolumn{4}{|c|}{ Median } \\
\hline Noise level & 3 & 2 & 4 & 3 \\
\hline Amount of Electric lighting & 4 & 3 & 4 & 3 \\
\hline Amount of daylight & 4 & 3 & 4 & 3 \\
\hline Glare level in the unit & 3 & 4 & 4 & 3 \\
\hline Glare level around your room & 3 & 3 & 4 & 3 \\
\hline Distance you are away from the window & 4 & 3 & 4 & 4 \\
\hline Unit temperature & 3 & 3 & 4 & 3 \\
\hline Ventilation & 4 & 4 & 4 & 4 \\
\hline Amount of air movement & 4 & 3 & 4 & 3 \\
\hline Freshness of your unit & 3 & 3 & 4 & 3 \\
\hline Humidity level in the unit & 3 & 3 & 4 & 3 \\
\hline Odour in the unit & 4 & 3 & 4 & 3 \\
\hline Your health when in the unit & 4 & 3 & 4 & 3 \\
\hline Colours of the unit & 4 & 3 & 4 & 3 \\
\hline Attractiveness of the unit & 3 & 3 & 4 & 3 \\
\hline Control over the local environment & 3 & 3 & 4 & 3 \\
\hline Privacy in a unit & 3 & 3 & 4 & 3 \\
\hline Unit in general & 3 & 3 & 4 & 3 \\
\hline Outward appearance of your unit & 3 & 3 & 4 & 3 \\
\hline Amount of space & 3 & 3 & 4 & 3 \\
\hline
\end{tabular}

It was discovered that Apartment C respondents were satisfied with the IEQ of their unit with the average median of 4 on all aspects of IEQ compared to the other apartments. From the survey, the Apartment B residents were mostly dissatisfied with the noise level of their units with the median of 2 . One of the possible reasons for this issue is the surrounding area of the apartment. As mentioned, Apartment B is located within the 200-meter radius from the ELITE Highway which could contribute to the noise level of its surrounding produced by the highway users. Additionally, Apartment B is located opposite to an ongoing construction site, which might be the source of the noise that contributes to this dissatisfaction. It is without a doubt that a construction site tends to be noisy as it uses a number of heavy machineries and equipment such as crane, jackhammer, concrete mixer, and concrete spreader. According to US Food and Drug Administration in their Draft Environmental Impact Statement (1996), the noise emission level from the construction site are measured at 50 feet $(15.24 \mathrm{~m})$ and decreased over distance. They further pointed out that the air quality is affected during the progress of construction as they generated fugitive dust as they are airborne particles. They later elaborated that the small particles drift distance could travel several hundred feet, while large particles tend to settle within 20 to 30 feet $(6.1$ to $9.1 \mathrm{~m})$ from their source, as the distance is affected by the size of the particles, wind speed, and emission height.

\subsubsection{Important Aspects of IEQ from the Respondents Perspective}


Table 11 indicates the important factors of IEQ from the perspective of the respondents. Value 2 and 1 indicate "less important", while values 4 and 5 indicate "very important", and value 3 as "neutral". According to the participants, some of the most important elements to be considered in order to achieve proper IEQ in the unit are ventilation, control over the environment, and privacy of the unit

Table 11: Important Factors of Respondents on IEQ

\begin{tabular}{|c|c|c|c|c|}
\hline \multirow{3}{*}{ Factors } & \multicolumn{4}{|c|}{ Important Factor } \\
\hline & $\mathrm{A}$ & $\mathrm{B}$ & $\mathrm{C}$ & $\mathrm{D}$ \\
\hline & \multicolumn{4}{|c|}{ Median } \\
\hline Noise level & 4 & 4 & 4 & 4 \\
\hline Amount of Electric lighting & 4 & 4 & 4 & 4 \\
\hline Amount of daylight & 4 & 4 & 5 & 4 \\
\hline Glare level in the unit & 4 & 4 & 4 & 4 \\
\hline Glare level around your room & 4 & 4 & 4 & 4 \\
\hline Distance you are away from the window & 4 & 4 & 5 & 4 \\
\hline Unit temperature & 4 & 5 & 5 & 4 \\
\hline Ventilation & 5 & 5 & 5 & 4 \\
\hline Amount of air movement & 4 & 5 & 5 & 4 \\
\hline Freshness of your unit & 4 & 4 & 5 & 4 \\
\hline Humidity level in the unit & 4 & 4 & 5 & 4 \\
\hline Odour in the unit & 5 & 4 & 5 & 4 \\
\hline Your health when in the unit & 5 & 5 & 5 & 4 \\
\hline Colours of the unit & 4 & 4 & 5 & 4 \\
\hline Attractiveness of the unit & 4 & 4 & 4 & 4 \\
\hline Control over the local environment & 5 & 5 & 5 & 4 \\
\hline Privacy in a unit & 5 & 5 & 5 & 4 \\
\hline Unit in general & 4 & 4 & 5 & 4 \\
\hline Outward appearance of your unit & 4 & 4 & 5 & 4 \\
\hline Amount of space & 4 & 4 & 5 & 4 \\
\hline
\end{tabular}

Based on the survey, the health of the residents did change according to the IEQ of the unit. Moreover, the residents did experience SBS symptoms upon living in their affordable unit. Most frequent symptoms they experienced are headache, fatigue, sneezing, stress, coughing, and sinus. This shows that the IEQ of the unit affects the health of the residents both physically and mentally. Next, it was discovered that the respondents' satisfaction level towards IEQ is neutral. However, there are some dissatisfaction towards the noise level between the units. Furthermore, the most important variables from the perspective of the residents are ventilation, privacy, and control over the environment, for instance, control over ventilation.

\subsection{Factor Analysis}

The purpose of the factor analysis is to categorize the variables of IEQ into groups. This factor analysis was made by analysing the twenty items of IEQ found in the literature review and the data from the questionnaire survey. The groups found are then named based on the items collected in the divided groups. In order to achieve this, the KMO and Bartlett's ests were used as shown in Table 12. The acceptable factor analysis for the KMO measurement is value $>0.7$ while Bartlett's Test is significant (sig.) value of 0.000 , with the $\mathrm{p}$-value of $<0.05$. The reading shows the correlation and the relationship among the twenty variables.

Table 12: KMO and Bartlett's Test

\begin{tabular}{|c|c|c|}
\hline $\begin{array}{l}\text { Kaiser-Meyer-Olkin } \\
\text { Sampling Adequacy }\end{array}$ & Measure of & .902 \\
\hline $\begin{array}{l}\text { Bartlett's Test of } \\
\text { Sphericity }\end{array}$ & $\begin{array}{l}\text { Approx. Chi- } \\
\text { Square } \\
\text { df } \\
\text { Sig. }\end{array}$ & $\begin{array}{l}2096.808 \\
190 \\
.000\end{array}$ \\
\hline
\end{tabular}

The sample size $(n=132)$ used in this study is more than the number of items related to occupants' satisfaction (20 items). The KMO measure of sampling adequacy was calculated at 0.902, suggesting an acceptable sample for 
factor analysis. Other than that, Bartlett's Tests measures the null hypothesis that the original correlation matrix is an identity matrix. For these data, the Bartlett's Test of sphericity is highly significant $(\mathrm{p}<0.05)$ and therefore there are some relationships between the variables to be included in the analysis. Due to the nature of the calculation, the component section will be listed in numbers instead of names.

Table 13: Total Variance Explained

\begin{tabular}{l|ccc}
\hline Component & \multicolumn{3}{|c}{ Initial Eigenvalues } \\
\hline 1 & Total & \% of Variance & Cumulative \% \\
2 & 10.452 & 52.262 & 52.262 \\
1.647 & 8.236 & 60.498 \\
3 & 1.199 & 5.997 & 66.495 \\
4 & 1.113 & 5.567 & 72.062 \\
5 & .726 & 3.631 & 75.693 \\
6 & .698 & 3.490 & 79.184 \\
7 & .683 & 3.414 & 82.598 \\
8 & .567 & 2.835 & 85.433 \\
9 & .446 & 2.232 & 87.664 \\
10 & .410 & 2.048 & 89.713 \\
11 & .361 & 1.805 & 91.518 \\
12 & .320 & 1.602 & 93.119 \\
13 & .277 & 1.383 & 94.503 \\
14 & .223 & 1.113 & 95.616 \\
15 & .202 & 1.008 & 96.624 \\
16 & .193 & .965 & 97.589 \\
17 & .174 & .871 & 98.460 \\
18 & .119 & .593 & 99.053 \\
19 & .098 & .491 & 99.544 \\
20 & .091 & .456 & 100.000 \\
\hline
\end{tabular}

Table 13 determines the number of categories to be formed. The component of 1 to 20 represents the "initial factor" of the 20 items affecting the IEQ in this survey. The significant part of this table is the "Total Eigenvalue" column. There are two ways to approach the eigenvalue.

The first approach is to refer the eigenvalue as the amount of information that is accounted for by the respective factors. The component with the total eigenvalue above 1 only can be retained. According to the table only component 1 until 4 with the eigenvalue above 1 . Thus, there are only four factors that can be retained from the 20 factors. The factors represent the number of categories created based on the 20 items. The eigenvalue of the first factor is 10.452, the second factor is 1.647 , the third factor is 1.199, and the fourth factor is 1.113. Since there are twenty items found, the total variance is equal to 20.00. Consequently, the value of $10.452,1.647,1.199$ and 1.113 of which twenty units of variance (i.e. 52.262\%, $8.236 \%, 5.997 \%$ and $5.567 \%$, respectively) are then accounted for by Factor 1, Factor 2, Factor 3 and Factor 4 respectively. In other words, the first four factors account for about $72.1 \%$ of the variance. The fifth eigenvalue, on the other hand, is substantially smaller. Since this value is below 1, the fifth factor hardly adds anything to the amount of variance explained. Therefore, there are only four factors being measured indirectly by the twenty items.

The second approach is by scree plot as in Figure 2. The purpose of the scree plot is to ensure the number of factors is retained as per Table 13

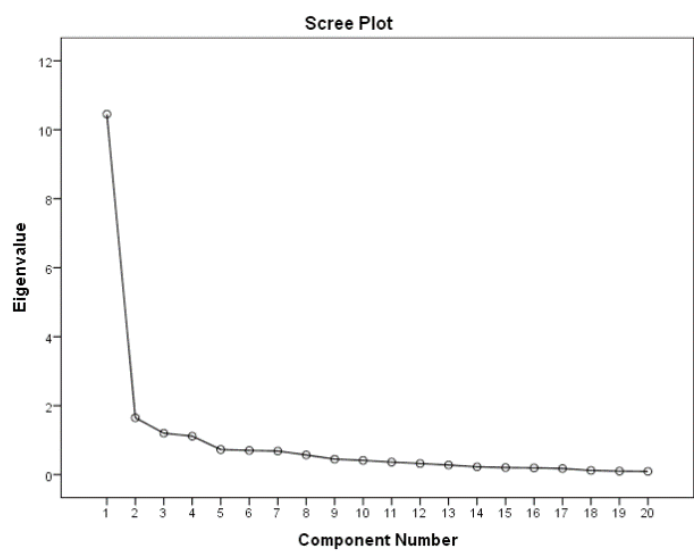

Figure 2: Scree plot of the eigenvalues against all factors

It confirms the conclusion that the twenty items are divided into four factors. This scree plot is a 
graphical representation of the eigenvalues of the different factors. The factors within the elbow of the graph are retained which are the factors 1 until 4 . This shows that the 20 variables affecting IEQ can be categorized into four groups, which should be named.

Table 14: Rotated component matrix result for factor distributions

\begin{tabular}{|c|c|c|c|c|c|}
\hline \multirow{2}{*}{ Items } & \multicolumn{4}{|c|}{ VARIMAX-rotated Loading } & \multirow{2}{*}{ Commonality } \\
\hline & Factor 1 & Factor 2 & Factor 3 & Factor 4 & \\
\hline Air Movement & .821 & & & & .805 \\
\hline Ventilation & .780 & & & & .815 \\
\hline Air Freshness & .750 & & & & .755 \\
\hline Electric & .714 & & & & .691 \\
\hline Humidity & .622 & & & & .647 \\
\hline State of Health & .615 & & & & .578 \\
\hline Temperature & .514 & & & & .565 \\
\hline Colours & & .845 & & & .836 \\
\hline Attractiveness & & .823 & & & .812 \\
\hline Outward Appearance & & .764 & & & .784 \\
\hline Noise Level & & .554 & & & .546 \\
\hline Unit General & & .486 & & & .732 \\
\hline Privacy & & & .798 & & .841 \\
\hline Amount of Space & & & .743 & & .790 \\
\hline Odour & & & .715 & & .693 \\
\hline Environment & & & .559 & & .743 \\
\hline Glare & & & & .862 & .813 \\
\hline Glare Outside & & & & .855 & .789 \\
\hline Distance Window & & & & .712 & .670 \\
\hline Daylight & & & & .509 & .509 \\
\hline
\end{tabular}

Extraction Method: Principal Component Analysis.

Rotation Method: Varimax with Kaiser Normalization converged in 6 iterations.

Table 14 above shows the rotated component matrix to ensure the factor structure is more interpretable. Before extraction, the commonalities are all 1 . The commonalities reflect the common variance in the data structure. About $80.5 \%$ of the variance associated with "air movement" is common or

shared variance. $19.5 \%$ variance will be explained by the other items. To conclude which items belong to which factor, the interpretation should start with the first item on the first factor and move horizontally from left to right, looking for the highest loading for that variable on any factor. In the table of the rotated matrix, the highest loading for "air movement" variable is 0.821 . The same process continues for each variable until "temperature" variable (loading 0.514) have been reviewed for their highest loading on Factor 1. Thus, those variables are underlined as Factor 1. However, there was a sudden jump in the loading value at "colours" variable after "temperature" variable. Thus, the highest loading for "colours" variable is 0.845 . The same procedure continued for the rest of the variables, suggesting there were seven items in Factor 1, five items in Factor 2, four items in Factor 3 and four items in Factor 4.

The names of these factors of IEQ is created by referring to the Rotated Component Matrix result (Table 14). The table has categorized four of the categories which are labelled as Factor 1, Factor 2, Factor 3 and Factor 4. Then, the factors are named according to the variables gathered under each factor, for example, Factor 1 contains items "Air Movement," "Ventilation," and "Air Freshness", thus Factor 1 is labelled as "Air Quality." The process is then repeated throughout Factor 2 to Factor 4. Finally, the remaining factors are name as "Appearance" for Factor 2, "General" for Factor 3, and "Lighting" for Factor 4 as in Table 15. The Cronbach's alpha values for each factor were $0.915,0.893$, 0.875 , and 0.824 , respectively.

Table 15: Items ordered and grouped according to size

\begin{tabular}{lll}
\hline Factor 1: Air Quality & \\
1 & 0.821 & Amount of air movement
\end{tabular}




\begin{tabular}{lll}
2 & 0.780 & Ventilation \\
3 & 0.750 & Air freshness \\
5 & 0.714 & Amount of electric lighting \\
6 & 0.622 & Humidity level \\
7 & 0.615 & State of health \\
\hline Factor $2:$ Appearance & \\
1 & 0.845 & Colours of the unit \\
2 & 0.823 & Attractiveness of the unit \\
3 & 0.764 & Outward appearance \\
4 & 0.554 & Noise level \\
5 & 0.486 & Unit in general \\
\hline Factor $3:$ General & Privacy level between units \\
1 & 0.798 & Amount of space in the unit \\
2 & 0.743 & Odour in the unit \\
3 & 0.715 & Environment control \\
4 & 0.559 & Glare level in the unit \\
\hline Factor $4:$ Lighting & Glare level around the unit \\
1 & 0.862 & Distance from the window \\
2 & 0.855 & Amount of daylight \\
3 & 0.712 &
\end{tabular}

In conclusion, based on both survey and data analysis, the variables found are now divided into four categories, which are lighting factor, general factor, appearances factor, and air quality factor. These four factors along with its components should be considered in the future development of the affordable housing in Malaysia due to their impact towards IEQ of the space. Furthermore, these factors will affect the health of the residence as well as their productivity in both long-term and short-term, as well as physically and mentally.

\section{CONCLUSION}

This study explored the factors of IEQ and identified the effects of inadequate IEQ towards the residents' the health of the residents' living in an affordable housing in Malaysia. Moreover, the literature study found twenty variables that affected the IEQ of a place. An observation and questionnaire study were carried out in four affordable apartments within the Klang Valley, Malaysia. The data collected from 132 sets of the returned questionnaire were discussed and analysed. It was found that $63 \%$ of the respondents were owners and $34 \%$ of the residents were living in a household size of more than four people in a unit. Moreover, $63 \%$ of the residents had been living in their units for five years and $45 \%$ of the respondents spent up to 10 hours in their respective residents. Furthermore, $18 \%$ of the residents experienced the decrease in health while $48 \%$ of them had consulted with the doctors related to the SBS symptoms such as headache, sneezing, stress, coughing, and sinus. The respondents agreed that the most important factors of IEQ are ventilation, control over the environment, for instance, ventilation control, and lighting control, and finally, the privacy between the units. The environment of the apartments was observed beforehand and it was found that all four apartments were located close to the main highway such as the ELITE Highway and the East-West Link Expressway. Furthermore, one of the apartments was located near a construction site which influenced the noise level and the air quality surrounding the apartment. The twenty variables were then analyzed along with the data collected from the respondents to categorize the variables in groups using the KMO and Bartlett's Test. There are four main categories found that affected the IEQ, which were the air quality, appearance, general, and lighting factor.

In conclusion, the IEQ levels in affordable housing are still inadequate and impact the health conditions of the residents. Regardless, there are still some improvements that can be made to achieve an excellent IEQ in an affordable housing. The improvement on the indoor environment can significantly improve the health of the residents because poor and inadequate IEQ can impact the health and wellbeing of the occupants in short-term as well as long-term, on both physical and mental health of the occupants. From this study, the response of the respondents can be used as an indicator to improve the affordable housing for future development. As found in the study, aspects such as the location of the building and its surrounding should be taken into consideration in the planning process in the future development of affordable housing. The important factors such as acoustic level and 
building materials should be addressed beforehand. Furthermore, the control over the environment, ventilation, and privacy within and between the housing units should be considered because these factors are considered as important in the perspective of the residents.

\section{ACKNOWLEDGEMENTS}

This research is funded and supported by UMRG (RP015E-15SUS), University Malaya, Research Grant, Sustainability Science Research Cluster.

\section{REFERENCES}

Abdul-Wahab, S. A., En, S. C. F., Elkamel, A., Ahmadi, L., \& Yetilmezsoy, K. (2015). A review of standards and guidelines set by international bodies for the parameters of indoor air quality. Atmospheric Pollution Research. 6(5), 751-767.

Baqutaya, S., Ariffin, A.S., \& Raji, F. (2016). Affordable housing policy: Issues and challenges among middle-income groups. International Journal of Social Science and Humanity. 6(6), 433-436. Retrieved from DOI: 10.7763/IJSSH.2016.V6.686

Cauchemez, S., Carrat, F., Viboud, C., Valleron, A.J., \& Bolëlle. P.Y. (2004). A bayesian MCMC approach to study transmission of influenza: application to household longitudinal data. Statistics in Medicine. 23, 3469-3487.

Cooper G. L., Field, J., Goswami, U., Jenkins, R., \& Sahakian, B., J. (2009). Mental Capital and Well-being. Wiley-Blackwell: New York.

Crump, D. (2011). Climate Change - Health impacts due to changes in the indoor environment; Research needs. Web Report W28. Bedfordshire, Cranfield: Institute of Environment and Health.

Frontczak, M., \& Wargocki, P. (2011). Literature survey on how different factors influence human comfort in indoor environments. Building and Environment. 46(4), 922-937. Retrieved from https://doi.org/10.1016/j.buildenv.2010.10.02 $\underline{1}$

Gambero, D. (2014). Tackling the issue of affordable housing. Star Property News. Retrieved date, $4^{\text {th }}$ December 2016, from http://www.starproperty.my/index.php/article s/property-news/tackling-the-issue-ofaffordable-housing/

Hashim, Z. A., (2010). House price and affordability in housing in Malaysia, Akademika, 78, 37 - 46.

Haghighat, F., \& Donnini, G. (1999). Impact of psycho-social factors on perception of the indoor air environment studies in 12 office buildings. Building and Environment. 34(4), 479-503.

House, T., \& Keeling, M. J. (2009). Household structure and infectious disease transmission. Epidemiology and Infection, 137(5), 654661. Retrieved from http://doi.org/10.1017/S0950268808001416

Institute of Medicine. (2011). Climate change, the Indoor Environment, and Health. Washington, DC: The National Academies Press.

Kamaruzzaman, S. N., Egbu, C. O., Zawawi, E. M. A., Ali, A. S., \& Che-Ani, A.I. (2011). The effect of indoor environmental quality on occupants' perception of performance: A case study of refurbished historic buildings in Malaysia. Energy and Buildings. 43(2-3), 407-413.

Kee, T. (2014). Adaptive reuse of industrial buildings for affordable housing in Hong Kong, Journal of Design and Built Environment. 14(1), 1-14. Retrieved from https://ejournal.um.edu.my/index.php/jdbe/ar ticle/view/5343

Klepeis, N. K., Nelson, W. C., Ott, W. R., Robinson, J. P., Tsang, A. M., Switzer, P., Behar, J. V., Hern, S. C., \& Englemann, W. H. (2011). The national human activity pattern survey (NHAPS): A resource for assessing exposure to environmental pollution. Journal of Exposure Analysis and Environmental. 11(3), 231 - 252. Retrieved from

https://www.nature.com/articles/7500165\#ab stract

Lee, J., Je, H., \& Byun, J. (2011). Well-being index of super-tall residential buildings in Korea. Building and Environment. 46, 11841194. Retrieved from https://doi.org/10.1016/j.buildenv.2010.12.01 0

Ling, C. S., \& Almeida, S.J. (2016). Demystifying the affordable housing issue in Malaysia. Annual Report 2016. Kuala Lumpur: Bank Negara Malaysia. Retrieved from

https://www.bnm.gov.my/files/publication/ar /en/2016/cp04_002_box.pdf

Lim, S. (2016). Affordable housing and the emergence of a new norm. The Edge Property. Retrieved $4^{\text {th }}$ December 2016, from http://www.theedgeproperty.com.my/content/ 959872/affordable-housing-and-emergencenew-norm

LPPKN (Lembaga Penduduk dan Pembangunan Keluarga Negara). (2013). Laporan Kajian Indeks Kesejahteraan Keluarga Malaysia 2011. Kuala Lumpur: LPPKN. Retrieved from 
http://www.lppkn.gov.my/index.php/ms/2014 -04-23-06-10-37/indeks-kesejahteraankeluarga/29-laporan-kajian-indekskesejahteraan-keluarga-malaysia2011/file.html

Malaysia Productivity Corporation. (2010). Sustainable Development Initiatives in Malaysia. Retrieved $18^{\text {th }}$ November 2016, from http://www.mpc.gov.my/wpcontent/uploads/2016/04/SustainableDevelopment-Initiatives-In-Malaysia.pdf

Martin-Gil, J., Yanguas, M. C., San José, J. F., Rey-Martinez, F.J., \& Martin-Gil, F.J. (1997). Outcome of research into a "sick" hospital. Hospital Management International. London: Sterling Publications Limited, 80 82.

Malina, N. J., Mahyudin, N., \& Akashah, F. W. (2017). Assessment on indoor environmental quality (IEQ) with the application of potted plants in the classroom: Case study of University Malaya, Journal of Design and Built Environment. 17(2), 1-15. Retrieved from

https://ejournal.um.edu.my/index.php/jdbe/ar ticle/view/10186/7227

Martellotta, F., Simone, A., Corciata, S. D., D'Alba, M. (2016). Global comfort and indoor environmental quality attributes for workers of a hypermarket in Southern Italy. Building and Environment. 95, 355 - 364.

National Institute for Occupational Safety and Health (NIOSH). (2013). Centre for Disease and Control Prevention, Indoor Environmental Quality. Retrieved from https://www.cdc.gov/niosh/topics/indoorenv/ default.html

$\mathrm{Ng}$, A. (2016). Housing Malaysians with affordable projects. Star Property News. Retrieved $4^{\text {th }}$ December 2016, from http://www.starproperty.my/index.php/article s/property-news/housing-malaysians-withaffordable-projects

Nimlyat, P. S., \& Kandar, M. Z. (2015). Appraisal of indoor environmental quality (IEQ) in health care facilities: A literature review. Cities and Society. 17: 66-68.

Norhidayah, A., Chia-Kuang, L., Azhar, M. K., \& Nurulwahida, S. (2013). Indoor air quality and sick building syndrome in three selected building. Procedia Engineering. 53, 93 - 98.

Plan, E. M. (2015). Eleventh Malaysia Plan, 2016-2020: Anchoring Growth on People. Putrajaya: Percetakan Nasional Malaysia Berhad. Retrieved from http://rmk11.epu.gov.my/book/eng/EleventMalaysia-Plan/RMKe-11\%20Book.pdf

REHDA. (2015). Report of Summary of Budget 2016 in relation to the Property Industry. Bulletin 11-12, November-December.
Retrieved from http://rehda.com/wpcontent/uploads/2016/03/REHDA-Bulletin11-12-November-December-2015.3.pdf

Schweizer, C., Edwards, R. D., Bayer-Oglesby, L., Gauderman, W. J., Ilacqua, V., Jantunen, M. J., Lai, H. K., Nieuwenhuijsen, M., \& Kunzli, N. (2007). Indoor timemicroenvironment-activity patterns in seven regions of Europe. Journal of Exposure Science \& Environmental Epidemiology. 17(2), 170-181.

United States Environmental Protection Agency (EPA) (1991), Indoor air facts no. 4 (revised): Sick building syndrome. Research and Development. Washington D.C: US. Retrieved from https://www.epa.gov/sites/production/files/20 14-08/documents/sick_building_factsheet.pdf United States Food and Drug Administration. (1996). Draft environmental impact statement: Prepared by Edwards and Kelcey, Inc. for the U.S. Food and Drug Administration. New York: General Service Administration.

Yousef, A. H., Arif, M., Katafygiotou, M., Mazroei, A., Kaushik, A., \& Elsarrag, E. (2016). Impact of indoor environmental quality on occupant well-being and comfort: A review of the literature. International Journal of Sustainable Built Environment. 5(1), 1-11 